\title{
Civil disabilities: Citizenship, membership, and belonging.
}

\section{A review}

\author{
Shauna Cappe \\ York University
}

Hirschmann, N. J. \& Linker, B. (eds.) (2015) Civil disabilities: citizenship, membership, and belonging. Philadelphia: University of Pennsylvania Press.

Nancy Hirschmann and Beth Linker edited a collection of essays that deal with various topics in the history and current situation of people with disabilities in America. The essays in Civil Disabilities expertly navigate the contours of ableism and citizenship to provide historical and analytical context to the lived experiences of disability in America. While the editors point out and recognise how American scholarship has not adequately developed the concept of citizenship in reference to Americans with disabilities, they draw on Canadian authors and their more nuanced study of citizenship and disability to frame the chapters in this volume. The authors do, however, draw on the rich American literature of citizenship, such as that developed by Martin Luther King and Ruth Bader Ginsburg. This collection of essays in an important step forward in the application of those foundational concepts to the study of disability in America.

The struggle of defining disability comes to the fore in chapter one as Susan Schweik uses a linked series of cultural texts to demonstrate the complexity of defining disability and disabilities, especially where multiple disabilities obscure one another, both within and between subjects. This chapter reveals the problematic ways that disability is portrayed, and how this can run counter to the interests of disability advocacy groups in their emancipatory efforts. In contrast, Faye Ginsburg and Rayna Rapp, in chapter five, point out some success stories of portrayals of disability in the media, but also emphasize how the mainstream media is still far from inclusive of disability. Each of these authors points out the ways in which the portrayals of disability in the mainstream media may be problematic, and how applying a critical lens in the study of these media portrayals is crucial in advocating for greater inclusion and sensitivity.

The definition of disability is a particularly poignant issue in American immigration policy, as explained by Douglas Baynton in chapter two. Disability has remained one of the primary identifiers by which a person may be discriminated against in American policy, and Baynton problematizes this legacy of discrimination in his interpretation of the ways in which immigration policy has been implemented to produce an economically productive society in America. This legacy relates well to the following chapter in which Susan Burch and Hannah Joyner interrogate accounts of American history, drawing attention to the ways in which the histories of people with disabilities have been "disremembered."

One of the key themes in this book is identity, and the ways in which the idea of disability identity has been used and subverted in the pursuit of different political goals. Catherine Kudlick (in chapter seven) describes how French society, from the mid eightenth century onwards, tried to subsume the identity of people with visual impairments into larger French society by finding ways to educate them on French heritage and ideals without any reference to their identity as people with visual impairments. In chapter 11, Tobin Siebers problematizes modern notions of

Corresponding author: Shauna Cappe (scappe@yorku.ca) 
identity politics that seek to obscure differences in the hope of obscuring the inequalities implicit in differences in modern society.

The strength of this book lies in its readings of texts in different media and historical contexts to bring together the themes of citizenship and identity that shape so much of the disability rights movement. Acknowledging where the literature has not yet progressed, this book attempts to further the discourse in disability studies through its unapologetic analysis of cherished historical legacies, films, histories, and policies that seek to problematize the ways that people with disabilities have found themselves as the objects of policy, rather than its writers.

One constructive point to offer regarding Civil Disabilities concerns the explanation provided with regard to citizenship. The authors acknowledge how American disability scholarship has not engaged in citizenship studies to the same degree as Canadian disability scholars. It would have been helpful, as context for the following chapters, to provide some background on the American concept of citizenship as it has been applied in other instances. Doing so would have provided crucial context regarding American immigration policy and the rendering of American history, topics of chapters in this book.

Civil Disabilities provides readers with valuable context and analysis, whether the reading is approaching the topic from the perspective of critical disability studies or the study of American history and policy.

\section{Author biography}

Shauna Cappe is a $\mathrm{PhD}$ candidate at York University in the department of Kinesiology and Health Science. Her research interests include critical disability studies, policy analysis, adapted physical activity and sport, and qualitative methods. Shauna's PhD dissertation is a policy analysis of Canadian Sport Policy, focusing on the policy's definition of and engagement with disability. 